\title{
DAMPAK PELABUHAN PERIKANAN SAMUDERA KENDARI TERHADAP KONDISI SOSIAL EKONOMI MASYARAKAT NELAYAN DI KECAMATAN ABELI KOTA KENDARI
}

\author{
Silviana ${ }^{1)}$ dan Muhammad Aswar Limi ${ }^{{ }^{*}}$ \\ Jurusan Agribisnis Fakultas Pertanian Universitas Halu Oleo Kendari Indonesia \\ ${ }^{*}$ Corresponding author : aswar_agribusiness@yahoo.com
}

To cite this article:

Silviana, S., \& Limi, M. (2020). Dampak Pelabuhan Perikanan Samudera Kendari terhadap Kondisi Sosial Ekonomi Masyarakat Nelayan di Kecamatan Abeli Kota Kendari. JIA (Jurnal Ilmiah Agribisnis) : Jurnal Agribisnis dan IImu Sosial Ekonomi Pertanian, 5(1), 35 - 41. doi:http://dx.doi.org/10.37149/jia.v5i1.9214

Received: October 29, 2019; Accepted: January 26, 2020; Published: January 30, 2020

\begin{abstract}
This study aims to determine how the impact of the Kendari Sea Fisheries Port on the socioeconomic conditions of the fishing community in the Abeli District. The determination of the study area was carried out by census sampling with 64 respondents. The method of data analysis uses descriptive qualitative analysis which consists of describing the facts, nature, and relationships between the phenomena encountered. Respondents' assessment of indicators measured with 5 Likert scales and the results of the Likert scale tabulation were analyzed using class intervals and interpretation in the form of a percent (\%). The results of the study note that the social impact of the existence of the Kendari ocean fishery port has an influence on the level of education and health level of fishermen and their family members as well as the absence of social change and social interaction between fishing communities while the economic impact of the existence of the Kendari ocean fishery port has an influence on employment opportunities in industries that there is a PPS in Kendari, the opportunity to try with the opening of business opportunities that can become opportunities for trading activities so as to increase the income of fishermen communities.
\end{abstract}

Keywords: economy; fishermen; ocean fishing port; social

\section{PENDAHULUAN}

Pelabuhan Perikanan Samudera merupakan infrastruktur dalam bidang perikanan sebagai pusat pengembangan perikanan, pusat kegiatan ekonomi perikanan (produksi, pengolahan, pemasaran produk perikanan) dan semua kegiatan masyarakat nelayan dapat difokuskan di pelabuhan perikanan yang berdampak positif pada pengembangan daerah sekitarnya. Pelabuhan perikanan memberikan dampak sosio-ekonomi yang timbul dari perkembangannya di kawasan pesisir yang dirasakan secara signifikan oleh para nelayan dan mampu menarik perhatian sektor hulu (Nurhadi \& Sumarsono, 2017; Suriadi, 2019)

Keberhasilan pengembangan dan pengelolaan pelabuhan perikanan, serta optimalisasi dalam kegiatannya merupakan tolok ukur keberhasilan pengembangan perikanan tangkap, yang pada akhirnya dapat meningkatkan kesejahteraan masyarakat, dapat memajukan perekonomian suatu wilayah dan dapat meningkatkan pendapatan daerah dan pendapatan negara. Yusliana \& Satlita (2017) pengembangan pelabuhan perikanan yang mampu beroperasi sesuai fungsinya secara optimal akan memberikan keuntungan bagi masyarakat nelayan dan memberikan dampak pada kesejahteraan masyarakat nelayan yang dapat dilihat melalui perkembangan usaha dan pembukaan lapangan pekerjaan atau lapangan pekerjaan yang baru bagi masyarakat nelayan yang bermukim disekitar, sehingga akan memberikan dampak terhadap nilai pendapatan masyarakat nelayan.

Pelabuhan Perikanan Samudera Kendari (PPS Kendari) adalah salah satu pelabuhan di kawasan Timur Indonesia yang telah ada sejak lama yang dapat memiliki dampak positif seperti terbuanya kesempatan bagi masarakat nelayan untuk bekerja dan peluang bagi anggota keluarga nelayan untuk membuka usaha dan memberikan membuka sektor jasa bagi masyarakat yang bermukim disekitar PPS Kendari. Nurhalimah et al (2017) pembangunan pelabuhan perikanan 
mengubah kondisi sosial-ekonomi masyarakat di sekitar Pelabuhan menuju kearah yang positif dengan lebih banyak peluang kerja, meningkatkan pendapatan masyarakat sekitar, semakin membaiknya tingkat keamanan dengan adanya kerjasama yang terjalin antara masyarakat nelayan dan masyarakat sekitarnya dengan pengelola pelabuhan perikanan, membaiknya fasilitas transportasi serta membaiknya infrastruktur pelabuhan perikanan. Selanjutnya (Sujarwo et al., 2014) perubahan yang dirasakan oleh masyarakat nelayan sekitar merupakan dampak akibat adanya perubahan kondisi fisik dan fasilitas pelabuhan serta perbaikan prasarana pelabuhan yang lebih baik dibandingkan sebelum adanya pelabuhan perikanan, penyerapan tenaga kerja dan meningkatnya pendapatan nelayan jika dibandingkan dengan sebelum adanya pelabuhan perikanan.

Semua potensi yang dimiliki oleh PPS Kendari terletak di Kelurahan Puday, Kecamatan Abeli melalui interaksi antara nelayan dan masyarakat sekitarnya karena tujuan pembangunan PPS Kendari adalah untuk meningkatkan kesejahteraan masyarakat nelayan dan juga meningkatkan pendapatan nelayan sebagai faktor yang menarik sehingga nelayan dapat memanfaatkan eksistensi dari PPS Kendari untuk menciptakan banyak lapangan kerja bagi nelayan. Putro (2016) pembangunan di daerah pesisir memiliki dampak positif pada nelayan dan masyarakat di daerah karena membuka peluang bagi masyarakat nelayan untuk memiliki lebih dari satu profesi (pekerjaan).

Kegiatan pengembangan PPS Kendari di Kelurahan Puday Kecamatan Abeli cukup penting untuk kehidupan sosial dan ekonomi masyarakat dan memiliki dampak yang baik pada keberlanjutan kondisi sosial dan ekonomi masyarakat melalui peningkatan pendapatan dan pembukaan lapangan pekerjaan. Selama ini, pengukuran dampak keberadaan PPS Kendari terhadap kondisi sosial dan kondisi ekonomi nelayan dan masyarakat di Kelurahan Puday Kecamatan Abeli belum dilakukan dilakukan sehingga kondisi masyarakat nelayan di sekitar PPS Kendari tidak diketahui apakah pembangunan PPS Kendari memberikan perbedaan kondisi dengan kondisi masyarakat pesisir lainnya dimana kondisi sosial (pendidikan dan kesehatan, perubahan sosual dan interaksi sosial) dan kondisi ekonomi (kesempatan kerja, peluang usaha dan pendapatan) (Insyafrijal et al., 2018), sementara itu aspek sosial dan ekonomi adalah topik penting dalam perencanaan, pelaksanaan dan evaluasi pembangunan dan pengembangan (Soemarwoto, 1997; Hadi, 1997). Berdasarkan keadaan tersebut maka tujuan penelitian ini adalah bagaimana pengaruh dari dampak pelabuhan perikanan laut Kendari terhadap kondisi sosial dan kondisi ekonomi masyarakat nelayan di Kecamatan Abeli, Kota Kendari.

\section{MATERI DAN METODE}

Penelitian dampak pelabuhan periknana samudera dilakukan pada tahun 2019 di kecamatan Abeli. Penentuan lokasi ditetapkan dengan sengaja, di Kelurahan Puday, yang terletak di sekitar Pelabuhan Perikanan Samudera Kendari (PPS Kendari), yang lokasinya sangat dekat dengan PPS Kendari. Populasi dari penelitian ini adalah kepala keluarga nelayan di pantai Kelurahan Puday sebanyak 64 kepala keluarga yang bekerja sebagai nelayan. Penentuan jumlah sampel ditentukan secara sensus sehingga seluruh penduduk digunakan sebagai sampel. Jenis data yang yang digunakan berasal dari data primer melalui wawancara langsung dengan responden menggunakan kuesioner di lokasi penelitian dan data sekunder berasal dari instansi terkait dengan. Variabel dalam studi ini terdiri dari kondisi sosial (pendidikan dan kesehatan dengan pernyataan positif dan perubahan sosial dan interaksi sosial dengan pernyataan negatif) serta kondisi ekonomi (kesempatan kerja, peluang bisnis dan tingkat pendapatan dengan pernyataan positif). Penelitian ini menggunakan metode analisis kualitatif deskriptif yang menggambarkan dengan sistematis dengan data yang akurat tentang fakta, sifat dan hubungan antara fenomena yang dihadapi yang digunakan untuk menjawab tujuan penelitian. Penilaian responden terhadap indikator diukur dengan menggunakan lima Skala Likert yang sangat tidak berdampak sangat dengan berdampak pada pernyataan positif sehingga semakin tinggi skor berarti semakin baik dan sebaliknya skor yang lebih rendah berarti semakin sedikit tidak baik dan sebaliknya untuk pernyataan negatif. Hasil tabulasi dari Skala Likert kemudian dianalisis menggunakan interval kelas sesuai (Arikunto, 2008) dan untuk mengetahui interpretasi dalam bentuk persen (\%) menggunakan rumusnya menurut Almutahar et al (2015) yaitu:

$$
\%=\frac{\text { total skor }}{\text { skor tertinggi }} \times 100
$$

\section{HASIL DAN PEMBAHASAN}

\section{Karakteristik Responden}

Karakteristik responden merupakan gambaran identitas kepala keluarga nelayan untuk mengetahui kondisi status nelayan yang dapat dilihat pada Tabel 1: 
Tabel 1. Karakteristik responden

\begin{tabular}{|c|c|c|c|}
\hline Karakteristik & Satuan & Frekuensi & Persentase (\%) \\
\hline \multicolumn{4}{|l|}{ Umur } \\
\hline $15-54$ & Tahun & 58 & 91 \\
\hline$>54$ & Tahun & 6 & 9 \\
\hline \multicolumn{4}{|l|}{ Pendidikan } \\
\hline SD & & 41 & 64 \\
\hline SLTP & & 17 & 27 \\
\hline SMA & & 6 & 9 \\
\hline \multicolumn{4}{|l|}{ Pengalaman } \\
\hline$<5$ & Tahun & - & - \\
\hline $5-10$ & Tahun & 30 & 47 \\
\hline$>10$ & Tahun & 34 & 53 \\
\hline \multicolumn{4}{|l|}{ Tanggungan Keluarga } \\
\hline $1-3$ & Orang & 20 & 31 \\
\hline $4-6$ & Orang & 34 & 53 \\
\hline$>6$ & Orang & 10 & 16 \\
\hline \multicolumn{4}{|l|}{ Pendapatan } \\
\hline < Upah Minimum Kota Kendari (2.551.463) & Rp/Bulan & 53 & 83 \\
\hline > Upah Minimum Kota Kendari (2.551.463) & Rp/Bulan & 11 & 17 \\
\hline
\end{tabular}

Sumber: Data primer diolah, 2019

Menurut Almutahar et al (2015); Aprilyanti (2017) faktor usia memiliki pengaruh pada produktivitas kerja di perusahaan. Berdasarkan Tabel 1 menunjukkan bahwa usia kepala keluarga nelayan di Kelurahan Puday, Kecamatan Abeli berusia produktif sebanyak 58 orang atau $91 \%$. Menurut Muawanah et al (2017) nelayan memiliki usia yang bervariasi dan sebagian besar pada usia produktif. Nelayan yang produktif memiliki kemampuan fisik dan kemampuan berpikir yang baik. Usia produktif responden di lokasi sangat mempengaruhi kinerja kerja yang didukung oleh kemampuan fisik dan cara berpikir dalam memecahkan masalah yang berkaitan dengan kegiatan bisnis seharihari, sehingga diketahui bahwa populasi usia produktif umumnya memiliki bisnis mereka sendiri dan dapat membantu keberhasilan program pemerintah (Sukmaningrum \& Imron, 2017).

Pendidikan yang lebih tinggi akan memiliki pengetahuan yang lebih luas dan wawasan dan cara berpikir yang lebih rasional. Ismadani (2015) pendidikan dan lingkungan kerja yang lebih baik maka semakin baik kinerjanya. Tabel 1 menunjukkan bahwa nelayan di Kelurahan Puday umumnya memiliki pendidikan formal dan didominasi oleh pendidikan sekolah dasar dengan 41 responden atau $64 \%$, pendidikan formal SMP dengan 17 responden atau $27 \%$ dan pendidikan sekolah tinggi dengan 6 orang atau sebanyak $9 \%$. Hasil ini menunjukkan bahwa mayorias pendidikan nelayan hanya sampai pendidikan dasar karena sejak kecil telah ikut orang tua melaut dan lebih memilih bekerja sebagai nelayan untuk memenuhi kebutuhan hidup daripada mengikuti pendidikan sehingga dapat dikatakan bahwa responden hanya memiliki pengetahuan dasar untuk mengembangkan bisnis mereka, tetapi umumnya nelayan telah berpengalaman berdasarkan Tabel 1 dimana responden lebih dominan dalam kategori berpengalaman dengan 34 responden atau $53 \%$, sehingga dapat dikatakan bahwa responden memiliki pengalaman dan pengetahuan untuk meningkatkan pendapatan keluarga mereka. Pengalaman dalam berusaha oleh responden sangat berpengaruh dalam keahlian dan kreativitas mereka dalam mempertahankan dan mengelola usaha yang mereka jalankan. Pengalaman dalam mencoba akan selalu membawa perubahan bagi responden dalam mengelola usaha mereka. Pengalaman yang telah dilalui akan menjadi bahan acuan untuk meningkatkan produktifitas dengan menjalankan kegiatan usaha kearah yang lebih baik. Aprilyanti,(2017) faktor kepemilikan kerja memiliki pengaruh pada produktivitas kerja di perusahaan.

Purwanti \& Rohayati (2014) semakin tinggi jumlah tanggungan keluarga, maka partisipasi kerja anggota keluarga akan lebih tinggi. Berdasarkan Tabel 1 menunjukkan jumlah tanggungan keluarga responden di Kelurahan Puday Kecamatan Abeli sebagian besar dikategorikan sebagai kategori keluarga moderat yaitu 34 orang atau $53 \%$ dan diikuti dengan kategori keluarga kecil yang sebanyak 20 orang atau $31 \%$, sedangkan untuk kategori keluarga besar yaitu 10 orang atau $16 \%$, maka berdasarkan hal itu dapat dilihat bahwa beban keluarga nelayan cukup tinggi untuk menanggung biaya anggota keluarga. Menurut Purwanti \& Rohayati (2014) sejumlah besar tanggungan keluarga juga membutuhkan biaya hidup yang tinggi sehingga akan meningkatkan partisipasi kerja anggota keluarga lain sehingga pendapatan juga meningkat. Tuntutan pemenuhan kebutuhan keluarga baik (konsumsi, pendidikan dan kesehatan), membuat anggota keluarga 
termasuk istri nelayan datang untuk bekerja sehingga partisipasi kerja perempuan juga meningkat. Purwanti \& Rohayati (2014) ada pengaruh signifikan terhadap jumlah tanggungan keluarga terhadap partisipasi pekerja perempuan.

Purwanti \& Rohayati (2014) ada efek pendapatan yang signifikan pada partisipasi buruh pekerja perempuan. Untuk meningkatkan pendapatan keluarga, istri nelayan juga bekerja untuk meningkatkan pendapatan sehingga partisipasi pekerja perempuan di industri meningkat. Berdasarkan Tabel 1 menunjukkan total pendapatan keluarga nelayan di Kelurahan Kecamatan Abeli Puday berkisar dari Rp1,000,000/bulan sampai Rp3,500,000/bulan dan kebanyakan dari mereka memiliki pendapatan di bawah upah minimum Kota Kendari tahun 2019 sebesar Rp2,551,463 sebanyak 53 rumah tangga atau $83 \%$ sementara mereka yang memiliki pendapatan di atas UMP adalah sebanyak 11 rumah tangga atau $11 \%$. Berdasarkan tabel tersebut diketahui bahwa yang menyebabkan istri nelayan bekerja di PPS Kendari dan berdagangan, yaitu untuk meningkatkan pendapatan keluarga dalam rangka memenuhi kebutuhan keluarga. Sitepu (1994) kegiatan kawasan industri memiliki dampak positif terhadap pendapatan masyarakat sekitar sehingga masyarakat mampu meningkatkan taraf hidup mereka karena sudah memiliki sumber mata pencaharian yang permanen.

\section{Dampak Pelabuhan Perikanan Laut Kendari Terhadap Kondisi Sosial Ekonomi Nelayan}

Moraes et al (2015); Cong et al (2020) pengembangan pelabuhan dengan fasilitas industri pengolahan dapat memiliki dampak positif dan tidak bisa diabaikan terhadap PDB per kapita kota dan menurut Morrissey et al (2019) dalam jangka pendek, investasi dalam mengembangkan sektor pelabuhan akan memiliki dampak positif secara keseluruhan terhadap perekonomian regional. Selanjutnya Morrissey et al (2019) dalam jangka menengah dan jangka panjang, investasi dalam pengembangan sektor pelabuhan akan berdampak pada tingkat pendapatan rumah tangga dan akan seimbang dengan rumah tangga yang kaya dan karyawan yang berpendidikan tinggi yang menerima manfaat terbesar. Sitepu (1994) terdapat hubungan yang signifikan antara dampak sosial dan ekonomi serta sosial dan budaya pada penyerapan tenaga kerja, peningkatan pendapatan dan pendidikan, fasilitas kesehatan, konflik sosial dan dampak sosial budaya terhadap sumber mata pencaharian, kehidupan sehari-hari, adat istiadat dan hubungan antar orang. Persepsi nelayan tentang dampak keberadaan pelabuhan perikanan Samudera Kendari di Kecamatan Abeli diukur sesuai dengan pendapat nelayan mengenai dampak pelabuhan perikanan Samudera Kendari tentang kondisi sosial (pendidikan, kesehatan, perubahan sosial, interaksi sosial) dan kondisi ekonomi (kesempatan kerja, peluang bisnis, tingkat pendapatan). Dampak pelabuhan perikanan laut (PPS) pada kondisi sosial ekonomi nelayan terdapat pada Tabel 2.

Tabel 2. Dampak pelabuhan perikanan laut (PPS) pada kondisi sosial ekonomi nelayan

\begin{tabular}{clccc}
\hline \multirow{2}{*}{ Variabel } & \multicolumn{1}{c}{ Indikator } & $\begin{array}{c}\text { Total Skor } \\
\text { Jawaban }\end{array}$ & Kriteria & $\begin{array}{c}\text { Persentase } \\
\text { Pengaruh Dampak }\end{array}$ \\
\hline \multirow{3}{*}{ Sosial } & Pendidikan & 782 & Berpengaruh & 81.45 \\
\cline { 2 - 5 } & Kesehatan & 735 & Berpengaruh & 76.56 \\
\cline { 2 - 5 } & Perubahan Sosial & 517 & Cukup Berpengaruh & 53.85 \\
\cline { 2 - 5 } & Interaksi Sosial & 420 & Cukup Berpengaruh & 43.75 \\
\hline \multirow{2}{*}{ Ekonomi } & Kesempatan Kerja & 857 & Berpengaruh & 89.27 \\
\cline { 2 - 5 } & Kesempatan Berusaha & 851 & Berpengaruh & 88.64 \\
\cline { 2 - 5 } & Pendapatan & 565 & Berpengaruh & 88.28 \\
\hline
\end{tabular}

Sumber :Data Primer diolah, 2019

Menurut Sitepu (1994) keberadaan kawasan industri telah memotifasi masyarakat berusahan untuk meningkatkan pendidikan anggota keluarga untuk melanjutkan pendidikan begitu besar. Berdasarkan Tabel 2, diketahui bahwa mayoritas responden menyatakan bahwa keberadaan PPS Kendari mempengaruhi kondisi pendidikan anggota keluarga nelayan dengan efek persentase $81,45 \%$. Hal ini dikarenakan di sekitar komplek PPS Kendari terdapat fasilitas pendidikan berupa TK yang didirikan dan dikelola oleh karyawan PPS Kendari. Keberadaan TK/PAUD membuat lebih mudah bagi anak nelayan untuk melanjutkan pendidikan khususnya bagi mereka yang tinggal di PPS Kendari karena jaraknya yang dekat. Keberadaan PPS Kendari telah menciptakan lapangan kerja bagi para nelayan dan anggota keluarga lainnya sehingga memudahkan anak nelayan untuk melanjutkan pendidikan karena nelayan dan anggota keluarganya telah memiliki pendapatan yang diperoleh bekerja di PPS Kendari. Limi (2018) pembangunan infrastruktur di wilayah pesisir Teluk 
Kendari meningkatkan keinginan anggota keluarga nelayan untuk ikut serta dalam pendidikan dan berharap nantinya mereka dapat bekerja dan bersaing dengan para migran di pesisir Teluk Kendari.

Menurut Sitepu (1994) keberadaan kawasan industri membuat orang ingin mendapatkan fasilitas pelayanan kesehatan yang lebih baik. Berdasarkan Tabel 2, dapat dilihat bahwa sebagian besar jawaban responden menyatakan bahwa keberadaan PPS Kendari memiliki efek pada kondisi kesehatan nelayan dan anggota keluarga mereka dengan efek persentase $76,56 \%$. Di sekitar kompleks PPS Kendari terdapat fasilitas kesehatan berupa Posyandu yang dikelola oleh lbu dasawisma dan para karyawan PPS Kendari. Dengan Posyandu, lebih mudah bagi para istri nelayan untuk mengakses fasilitas kesehatan yang memberikan pemeriksaan gratis terhadap anak dan wanita hamil. Keberadaan PPS Kendari berdampak positif terhadap kesejahteraan masyarakat nelayan (Kesehatan). Menurut Undang-Undang Republik Indonesia Nomor 11 Tahun 2009 Tentang Kesejahteraan Sosial (2009) bahwa bidang kesejahteraan sosial sangat luas dan kompleks, yang meliputi aspek pendidikan dan kesehatan dengan menyediakan infrastruktur dasar berupa sarana pendidikan dan kesehatan bagi anggota keluarga untuk menciptakan kesejahteraan sosial bagi masyarakat.

Perubahan sosial terlihat melalui perubahan hubungan interaksi sosial antara nelayan, organisasi serta komunitas mereka. Perubahan sosial di kalangan nelayan memerlukan suatu proses yang terjadi dengan sendirinya dan secara umum merupakan faktor yang berkontribusi untuk mewujudkan perubahan sosial dalam masyarakat nelayan, faktor pendorong perubahan adalah konflik yang dapat terjadi di mana suatu kelompok benar-benar bersikeras mengikuti norma sendiri. Berdasarkan Tabel 2, diketahui bahwa mayoritas jawaban responden menyatakan bahwa keberadaan Kendari PPS cukup berpengaruh terhadap perubahan sosial dengan persentase efek sebesar $53,85 \%$ karena potensi konflik. Potensi konflik dapat terjadi karena adanya PPS Kendari karena beredarnya minuman beralkohol yang dianggap sebagai obat kelelahan atau meredakan kelelahan bagi nelayan yang diminum tidak sampai mabuk atau meresahkan masyarakat sekitar tetapi dapat memicu konflik jika dikonsumsi secara berlebihan sehingga dianggap sebagai dampak negatif di tengah masyarakat. Limi (2018) potensi terjadinya konflik di daerah pesisir Teluk Kendari cukup kecil karena tersedianya lapangan kerja bagi masyarakat pesisir sehingga semua sibuk dengan setiap pekerjaan yang mereka lakukan.

Interaksi sosial merupakan kunci kehidupan sosial dan setiap manusia akan selalu berinteraksi satu sama lain sebagai wujud kehidupan bersama-sama. Gerungan (2010) mengatakan bahwa interaksi sosial merupakan hubungan sosial dua atau lebih individu yang memiliki perilaku berasal dari satu pengaruh individu, perubahan atau meningkatkan perilaku individu lain atau sebaliknya. Interaksi sosial yang dimaksud dalam kajian ini adalah hubungan sosial yang terjadi di masyarakat karena adanya PPS Kendari. Berdasarkan Tabel 2, diketahui bahwa mayoritas jawaban responden menyatakan bahwa keberadaan Kendari PPS cukup berpengaruh pada interaksi sosial dengan persentase efek $43,75 \%$. Hubungan interaksi sosial di lokasi studi dengan kehadiran PPS Kendari tidak mengubah perilaku individu atau kelompok. Limi (2018) keberadaan PPS Kendari membuat nelayan beralih mata pencaharian mereka ke darat sehingga para nelayan berkesempatan untuk bekerjasama dan menghadiri pertemuan masyarakat di daerah pesisir sehingga tidak menimbulkan konflik sosial di pesisir Teluk Kendari. Keberadaan PPS Kendari tidak mengurangi kesediaan warga untuk saling membantu, kerjasama dalam melakukan kegiatan masyarakat seperti kegiatan Jum'at bersih di mana komunitas nelayan di Kelurahan Puday melakukan kegiatan kerjasama untuk membersihkan lingkungan diwilayah PPS Kendari dan menjaga hubungan baik antara para ibu nelayan yang akan saling membantu dalam setiap perayaan dan kegiatan kesehatan. Limi (2018) pembangunan di wilayah pesisir Teluk Kendari tidak mempengaruhi bentuk kerja sama dan pertemuan masyarakat di daerah pesisir dan tidak menimbulkan konflik sosial di wilayah pesisir Teluk Kendari.

Semakin meningkatnya perkembangan pembangunan, semakin besar peluang kerja yang tersedia. Ini berarti bahwa semakin besar permintaan untuk tenaga kerja. Kesempatan kerja yang dimaksud dalam kajian ini adalah kesempatan bagi masyarakat nelayan dan para anggotanya untuk bekerja di industri yang berada di daerah PPS Kendari. Berdasarkan Tabel 2, diketahui bahwa mayoritas jawaban responden menyatakan bahwa keberadaan PPS Kendari mempengaruhi peluang kerja di Kelurahan Puday, Kecamatan Abeli dengan persentase efek sebesar 89,27\%. Dengan adanya PPS Kendari, pekerjaan baru akan dibuka untuk anggota keluarga nelayan yang memiliki pendidikan. Wang (2020) pembangunan daerah berdampak pada penciptaan lapangan kerja dan memiliki dampak yang sangat signifikan pada pendapatan. Keinginan untuk meningkatkan pendapatan mendorong anggota keluarga nelayan untuk bekerja di luar nelayan seperti istri dan anggota keluarga nelayan yang bekerja di industri yang terdapat di PPS Kendari. Jika hasil tangkapan melimpah, beberapa industri membutuhkan banyak karyawan, salah satunya adalah 
industri pengolahan ikan, yaitu CV. Mina Jaya Lestari (industri pengolahan ikan). Dimana setiap minggu diberikan upah Rp. 550.000/minggu sesuai banyaknya ikan.

Peluang kerja didefinisikan sebagai pekerjaan atau kesempatan yang tersedia untuk bekerja di PPS Kendari sebagai hasil dari kegiatan ekonomi. Sitepu (1994) keberadaan kawasan industri telah membuat masyarakat nelayan tertarik membuka usaha karena tingginya permintaan pemenuhan kebutuhan sehari-hari karyawan yang banyak menetap di sekitar kawasan industri. Berdasarkan Tabel 2, diketahui bahwa mayoritas jawaban responden menyatakan bahwa eksistensi dari PPS Kendari berpengaruh pada peluang bisnis dengan persentase efek $86,94 \%$. Hal ini disebabkan keberadaan anggota keluarga yang bekerja di industri yang ditemukan di PPS Kendari dan keberadaan nelayan yang membuka usaha di sekitar PPS Kendari serta di samping menjadi buruh, pedagang ternak, pedagang kebutuhan pokok, bengkel dan kegiatan perdagangan lainnya. (Efendy, 1996) karena keberadaan perusahaan mendorong pengembangan kios, warung dan jasa perdagangan.

Suherman \& Dault (2009b) adanya fasilitas yang terdapat di pelabuhan perikanan nusantara dapat memberikan manfaat yang besar dalam memperbaiki kondisi sosio-ekonomi dan kesejahteraan hidup para nelayan. Pembangunan PPS Kendari diharapkan dapat meningkatkan pendapatan para nelayan ketika komplek PPS Kendari beroperasi sehingga pendapatan nelayan dapat dimaksimalkan. Salah satu faktor yang berpengaruh dalam perekonomian nelayan adalah tingkat pendapatan nelayan yang semakin baik. Berdasarkan Tabel 2, diketahui bahwa mayoritas jawaban responden menyatakan bahwa keberadaan PPS Kendari berpengaruh terhadap pendapatan keluarga nelayan dengan persentase efek sebesar $88,28 \%$. Meningkatnya pendapatan keluarga nelayan karena pendapatan sampingan nelayan dan anggota keluarga sebagai buruh dan penjualan di kompleks PPS Kendari. Suherman \& Dault (2009a) dampak positif pembangunan pelabuhan perikanan nusantara, yaitu peningkatan usaha dan pembukaan lapangan kerja baru atau kesempatan kerja bagi masyarakat sekitar, yang akan mempengaruhi pendapatan dalam meningkatkan kondisi sosioekonomi dan kesejahteraan kehidupan nelayan. Lebih lanjut Tamrin (2017) kontribusi kelabuhan kepada masyarakat termasuk meningkatkan pendapatan nelayan dan pedagang.

\section{KESIMPULAN DAN SARAN}

Pelabuhan Perikanan Samudera Kendari memberikan dampak terhadap kondisi sosial ekonomi nelayan. Dampak sosial dari adanya PPS Kendari yaitu memberikan dampak terhadap tingkat pendidikan dan kesehatan nelayan dan anggota keluarganya yang dapat memenuhi kebutuhan serta kesejahteraan keluarga nelayan, sedangkan dampak ekonomi adanya PPS Kendari yaitu memberikan dampak terhadap peningkatan tingkat pendapatan keluarga nelayan, adanya kesempatan kerja di industri-industri yang berada di kompleks PPS Kendari, serta terciptanya kesempatan berusaha melalui aktivitas berdagang dan kegiatan informal lainnya di sekitar PPS Kendari.

\section{REFERENCES}

Almutahar, F. F., Wardhani, N., \& Rafie. (2015). Pengaruh Usia, Pengalaman Kerja, Disiplin Kerja, dan Motivasi Kerja Terhadap Produktivitas Pekerja Pada Pekerjaan Pemasangan Dinding Batako. Jurnal UNTAN, $11(1), \quad 11$. http://jurnal.untan.ac.id/index.php/JMHMS/article/view/9815

Aprilyanti, S. (2017). Pengaruh Usia dan Masa Kerja Terhadap Produktivitas Kerja (Studi Kasus: PT. OASIS Water International Cabang Palembang). Jurnal Sistem Dan Manajemen Industri, 1(2), 68-72. https://doi.org/10.13140/RG.2.2.15858.61129

Arikunto, S. (2008). Prosedur Penelitian Suatu Pendekatan Praktik. Rineka Cipta.

Cong, L., Zhang, D., Wang, M., Xu, H., \& Li, L. (2020). The role of ports in the economic development of port cities: Panel evidence from China. Transport Policy, 90, 13-21. https://doi.org/10.1016/j.tranpol.2020.02.003

Efendy, M. (1996). Dampak Sosial Ekonomi dan Sosial Budaya Perkebunan Kelapa Sawit Perkebunan XII Kalimantan Barat. Tesis. Program Pascasarjana UI. Jakarta.

Gerungan, W. A. (2010). Psikologi Sosial. PT. Eresco.

Hadi, S. P. (1997). Aspek Sosial Amdal: Sejarah, Teori dan Metode. Gadjah Mada University Press.

Insyafrijal, I., Nasir, M., \& Abdullah, F. (2018). Dampak keberadaan Pelabuhan Perikanan Nusantara Idi Aceh Timur terhadap sosial ekonomi masyarakat nelayan. Depik: Jurnal IImu-IImu Perairan, Pesisir Dan Perikanan, 7(2), 100-110. https://doi.org/10.13170/depik.7.2.10033 
Ismadani, N. (2015). Pengaruh Tingkat Pendidikan Formal Dan Lingkungan Kerja Terhadap Kinerja Pegawai Di Kantor Kelurahan Gunungbahagia Kecamatan Balikpapan Selatan Kota Balikpapan. E-Journal Ilmu Pemerintahan, 3(1), 291-302.

Limi, M. A. (2018). Dampak Pembangunan Kawasan Pesisir dan Perubahan Lingkungan Terhadap Kondisi Sosial Ekonomi Budaya (Suatu Studi pada Nelayan di Teluk Kendari). Disertasi. Program Pascasarjana Universitas Halu Oleo.

Moraes, M. A. F. D., Oliveira, F. C. R., \& Diaz-Chavez, R. A. (2015). Socio-economic impacts of Brazilian sugarcane industry. Environmental Development, 16, 31-43. https://doi.org/10.1016/j.envdev.2015.06.010

Morrissey, K., Burthoo-Barah, S. B., Dawoonauth, M., \& Scandizzo, P. L. (2019). Exploring the distributional impact of investment in the port sector on households in Mauritius: A social accounting matrix approach. Marine Policy, 99(October 2018), 324-333. https://doi.org/10.1016/j.marpol.2018.10.047

Muawanah, U., Kusumaningrum, P. D., Nugroho, H., \& Daniel, D. (2017). Gambaran, Karakteristik Pengguna Dan Persepsi Nelayan Terhadap Kemanfaatan Sistem Aplikasi Nelayan Pintar (SINP) Di Pelabuhan Perikanan Indonesia. Jurnal Kebijakan Sosial Ekonomi Kelautan Dan Perikanan, 7(1), 63. https://doi.org/10.15578/jksekp.v7i1.6460

Nurhadi, N., \& Sumarsono, S. (2017). Analisis Dampak Pelabuhan Ikan - Ppn Prigi Terhadap Ekonomi Wilayah Kecamatan Watulimo, Kabupaten Trenggalek Dengan Metode InputOutput Analisis. Jurnal Kelautan: Indonesian Journal of Marine Science and Technology, 10(2), 185. https://doi.org/10.21107/jk.v10i2.3132

Nurhalimah, Marwanti, S., \& Irianto, H. (2017). Analisis Dampak Pembangunan Pelabuhan Perikanan Pantai Di Tamperan Kecamatan Pacitan Kabupaten Pacitan Terhadap Kondisi Sosial Ekonomi Masyarakat Sekitar. Agrista, 5(1), 191-203.

Purwanti, E., \& Rohayati, E. (2014). Pengaruh Jumlah Tanggungan Keluarga, Pendapatan Terhadap Partisipasi Kerja Tenaga Kerja Wanita Pada Industri Kerupuk Kedelai Di Tuntang, Kab Semarang. Jurnal Ilmiah Among Makarti, 7(13), 113-123. https://jurnal.stieama.ac.id/index.php/ama/article/view/102

Putro, R. (2016). Studi Deskriptif Dampak Perubahan Fungsi Wilayah Pesisir Pada Tingkat Kesejahteraan Ekonomi Masyarakat (Studi Kasus Pembangunan Terminal Multipurpose Teluk Lamong). Kebijakan Dan Manajemen Publik Volume, 4(April), 1-9.

Sitepu, P. (1994). Pemantauan Dampak Sosial Ekonomi dan Sosial Budaya Kawasan Industri Medan (KIM) Terhadap Masyarakat Sekitar. Tesis. Sekolah Pascasajana IPB. Bogor.

Soemarwoto, O. (1997). Analisis Mengenai Dampak Lingkungan (Gajah Mada University Press (ed.)).

Suherman, A., \& Dault, A. (2009a). Analisis Dampak Sosial Ekonomi Keberadaan Pelabuhan Perikanan Nusantara Brondong Lamongan Jawa Timur. Jurnal Saintek Perikanan, 5(1), 2530.

Suherman, A., \& Dault, A. (2009b). Dampak Sosial Ekonomi Pembangunan Dan Pengembangan Pelabuhan Perikanan Nusantara (PPN) Pengambengan Jembrana Bali. Indonesian Journal of Fisheries Science and Technology, 4(2), 24-32. https://doi.org/10.14710/ijst.4.2.24-32

Sujarwo, M. A., Mardiyono, \& Prasetya, W. Y. (2014). Evaluasi dampak kebijakan pembangunan Pelabuhan Perikanan Pantai (PPP) Tamperan terhadap perubahan sosial ekonomi masyarakat pesisir pantai (Studi kasus pada PPP Tamperan Kab. Pacitan). Jurnal Administrasi Publik (JAP), 2(11), 1010-1015.

Sukmaningrum, A., \& Imron, A. (2017). Memanfaatkan Usia Produktif Dengan Usaha Kreatif Industri Pembuatan Kaos Pada Remaja Di Gresik. Jurnal Paradigma, 5(3), 1-6. http://jurnalmahasiswa.unesa.ac.id/article/25663/39/article.pdf

Suriadi, A. (2019). Dampak Sosial Ekonomi Pembangunan Tanggul Pantai Di Teluk Jakarta Dan Strategi Mitigasinya. Jurnal Sosial Ekonomi Pekerjaan Umum, 11, 5-17.

Tamrin. (2017). Aktivitas Sosial Ekonomi Masyarakat Di Sekitar Pelabuhan Perikanan Waetauo Kecamatan Tanete Riattang Timur Kabupaten Bone Provinsi Sulawesi Selatan. Jurnal Agrominansia, 2(2), 157-161.

Undang-Undang Republik Indonesia Nomor 11 Tahun 2009 Tentang Kesejahteraan Sosial, (2009).

Wang, H. (2020). The economic impact of oil and gas development in the Permian Basin: Local and $\begin{array}{lllll}\text { spillover effects. Resources } & & \end{array}$ https://doi.org/10.1016/j.resourpol.2020.101599

Yusliana, \& Satlita, L. (2017). Dampak Pembangunan Pelabuhan Pendaratan Ikan Logending Terhadap Kesejahteraan Masyarakat Desa Ayah Kecamatan Ayah Kabupaten Kebumen. Adinegara, $6(3)$,

310-319. http://journal.student.uny.ac.id/ojs/index.php/adinegara/article/view/8959/0 